\title{
Et Bidrag til Modersmaalets Historie i Sundeved.
}

Meddelt af Lou is Bobé.

I Aaret 1735 udstedte Hertug Frederik af Glyksborg en Forordning, hvis 12. Paragraf lyder saaledes i Oversættelse: „Da der i Vort Distrikt Sundeved opholder sig særdeles mange, som slet ikke, eller kun i saa ringe Grad ere kyndige $i$ det danske Sprog, at de ej kunne forstaa de danske Prædikener, saa skal fra nu af hver 3. Søndag i Vore Kirker i Broager, Ullerup, Satrup og Nybel predikes paa tysk hver tredje Søndag og fortsættes saalunde til Stadighed; ligervis skal ogsaa Ungdommen i Skolerne undervises saavel i det tyske som i det danske Sprog."

Mod denne Kirkelov gjorde baade Hertugen af Augustenborg og Ejeren af Grevskabet Reventlow-Sandbjerg Grev C. D. Reventlow, hvem adskillige Bønder i de paagældende Sogne tilhørte, kraftig Indsigelse, idet de hævdede, at Hertugen af Glykshorg ikke kunde paalægge deres Undersaatter Afgifter til hans Kirker og Præster. Om Forordningens videre Skæbne henvises til C. F. Allen, Det danske Sprogs Historie $191 \mathrm{ff}$. Selve den juridiske Side af Sagen har kun saare ringe Interesse og skal her forbigaas.

Ved Sagens Akter i det glyksborgske Arkiv i Rigsarkivet findes bevaret de to nedenfor meddelte Bønskrifter til Grev Reventlow og Hertugen af Augustenborg fra dansktalende Undersaatter i Sundeved, der andrage deres Lehnsherrer om, at det for deres Vedkommende maatte have sit Forblivende ved den gamle Kirkeordning. Det første udaterede Andragende, som utvivlsomt er indsendt 
strax efter Forordningens Fremkomst, er undertegnet af 18 Bønder i Snabæk og 15 i Satrup; det er bevaret i Original, medens det andet, ligeledes udaterede, indsendt af Hertugrens Undersaatter paa Graasten og Auenbølgaard, kun er levnet i Afskrift. Begge Skrivelser, der ere affattede paa Dansk og meddeles her i bogrstavret Gjengivelse, afgive et smukt Vidnesbyrd om dansk Sindelag og Kjærlighed til Modersmaalet hos den sønderjydske Bonde. Særlig den første, der tydeligt nok ikke skyldes en betalt Skrivekyndik, men som er flydt en jævn Almuesmand i Pennen, vil ved sin djærve, varme og indtrængende Tone vinde Læserens Sympathi.

\section{Hoybaarne Herr Græffe, Naadigste Herre,}

Deris Høygræfl. Excell: samtlighe Underdaner udi Satrup og Schnabeck gifver udi all Underdanighed til Kiendte, hvorledes Hanss Hoyfürstl. Durchl. til Glücksburg for kort Tid udj Satrup Kircke en gandske uformodentlige Kirckeforordnung fra Predicke Stohlen publicere, derudj os alle som till denne Meenigheds Tillhorere imod dend gamle og till denne Tid brugelig hafver været Skicke og Ordnung, lade forfatte, derudi all nye Paalæg paabürdet vilde, som fra utaalig gammel Tid og saa lenge som Kirken hafver staed, alle Söndage her, savel som i det gansche Land hafrer vi hafft vor Predickerne paa det danske Sprog af hvilked vi er underviste $i$ fra vores Moders Fødsell, iligemaader voris Born ere oplærde udi dend danske Cathechismo, mens derimod skall hver triede Sondag predickes tyskt og voris Born tillige med skall lere dend tyske Catchesmo og andet mere som vi icke ere vened til fra Ungdom og icke begribe kand. 
Naadigste Herre, vi og voris Børn ere opføde udi det danske Sprog og er det best bekient og forstaar lidet eller inted af det tyske og gaar til Kircke saa at hore Guds Ord til voris Saligheds Forfremmelse; skall os nu herefter en ubevand og ganske ubekient Tale predickes, er inted andet ind at ganske afvisse os fra Guds Huss og hans helige Ord, og er at befrygte dersom dete icke i Tide blifver forlindret, herefter mere kunde os paabürdet blifve. Vi kunde aldrig troe at det er med Deris Hoygräfl. Vilie og Consens, efter de vi ofver de halfve ere af Deris Hoygrïfl. Underdaner mere ind de Gliicksburger som aarligen gifver Kircken, Presterne og Degen deris Gebör, derfor var billig at $i$ det forgaaendo os denne Befall hafde blefvet först forkündet om vi vilde det indgaa.

Deres Hoygräfl. Exell. som voris nadigste Øfrighed beder vi udi all Underdanighed og af Hiertensgrund, os som deris Underdaner hiertelig at antage, og udi jngen Maader at tillade, at det som fra gammel Tid hafver vered brugeligt aldeles icke blifver undertrygt

1. at os for det gammel icke blifver nye Oplage introducired,

2. at det ved dend gamle Kirckens Forordnung uforhindret blifve kand,

3. at alle Söndage, wie brugelig hafver vared, ved dend danske Predicken blifve kunde, og

4. at dend tyske Predickerne ganske maa hereffter blifve effterladt, tillmed for det

5. at voris Börn udi dend danske Cathechismus udi 
voris Skole uforhindret maa blifve fremfört som til denne Dag, og for det

6. at vores Börne Examen lige som tillforne udi dend danske Sprog kand blifve holden paa det, at for det

7. voris Bürn icke paa en ubekiendt Tilltalle og Sprog icke blifver udi deres Christendom forvildet, og for det

8. voris Communion hver Söndag matte blifve forrettet, till med for det

9. dersom imod Forhaabning det skulde skee, at denne nye Forordenung imod dend gammele skulde hafve sin Fremgang og icke bestaa ved dend gamle Foed, at vi, Deris Hoygräfl. Underdaner, som dend störrest Deel af voris Menighed, som underholder Kircken, Presten og Degen, at vi matte indholde voris Udgiffter, indtil det kommer paa dend gamle Skik igien. Vi sambtlige Deris Hoygräfl. Underdaner tröster os ved Deris Nadigste Forsvar, at Deris Hoygräfl. Excell. ingenlunde tillader, at ri som dend störeste Deel af Menigheden icke med nye Besvar blifve herefter presured, denne Befahl at antage, tröster os Deris Hoygräfl. Naade og Beskyttelse tilmed en naadige Bönhörelse og döer

Deris Hoygräffl. Excell.

Schnabeck underdanigste og tro Undersatter

Jörgen Christenssen Christen Hanssen Dall Jwer Christepssen
Sater u p. Ludwig Christian Schmit Peter Hindrigsen 


$\begin{array}{cc}\text { Peder Hüller } & \text { Christen Persen } \\ \text { Asmus Petersen } & \text { Peter Jensen Lyck } \\ \text { Christen Jörgensen } & \text { Jürgen Jürgensen } \\ \text { Rassmus Dall } & \text { Hans Claussen } \\ \text { Anders (?) Hansen } & \text { Hans Petersen } \\ \text { Christen Christensen } & \text { Hans Petersen Alsing } \\ \text { Anderss Christessen } & \text { Jörgen Jürgensen } \\ \text { Peter Paulsen } & \text { Hans Christessen } \\ \text { Christen Jwersen } & \text { Hindrig Jakobsen } \\ \text { Statz Petersen } & \text { Peter Jürgenssen } \\ \text { Jenss Hinrichssen } & \text { Christen Jürgensen } \\ \text { Hanss Hanssen } & \text { Asmus Chrestensen } \\ \text { Andreas Christenssen } & \text { Jackob Jörgenssen } \\ \text { Johann Assmussen } & \\ \text { Christen Markosen } & \end{array}$

\section{Durchl. Hertzog}

Naadigste Fürst og Herre.

Deris Hoy Fürstl. Durchl. udj störrste Underdanighed nodes vii til at forrestille hvorleedis Hertzogen til Lycksborg Hoy Fürstl. Durchl. for nogle Ugger siden haver en Kirke Forordning anordnedt, og deraf en Extract af Prædikestolene til Brauer, Nyffel, Satrup og Ullerup ladet publicere, hvorved uden adskillige Ratione om Offeret, Skrifft-Stoelen og hrorleedis med de Syge som ligger paa Deris Seng forlanger at blifve Jesu Christi Legom og Blood deelagtig, skall forholdes og andre os endnu ubekiendte forordnede Fornyelser, er dend uformodende Anstalt skeed, at i Stæden og forhend alle Syndage er blefven prædiket udj vores danske Tunge Maal, mens nu hereffter i det Lycksborgske og Sondewidsker Districter hver triedie Syndag skall holdes Prædiken udj det tydske Sprog, og dette er allerede af Præsterne paa for- 
nevfnte Stæder (: os arme Mennisker til Hiertens Kummer og Bedröfvelse :) bleven udj Agt tagen.

Som nu, Naadigste Fürst og Herre, udj ald dend Tiid vii med de Lychsborgske Undersatterne haver holden en Meenighed, da haver det vaaren brugeligt, at Guds Ord alle Tiider af Præsterne for os udj det danske Sprag og Tungemaal er blefven prædiket og forklaredt og os hereffter nödvendig udj samme danske Sprag skall vorde forklaredt i Henseende

2do. Nok som er bekiendt, at vii udj det danske Sprog og Tungemaal ligesom vore Forældere og voris Börn ligelcedis effter os er blefven underviist, udi samme Sprag, ja vores Christendoms Fundament er lagt formeedelst det danske Sprag, mens af det tydske Tungemaal forstaar vii $\mathrm{og}$ vores Börn, jo de fleeste, liedet eller intet og er det

3tio En pure Unuglighed, at vii af de nu nyelig anordnede tydske Prædikerne vores Börn og mange arme Folk, hvilke alle det tydske Sprag er ubekiendt, kunde udj vores Cristendom og Saligheds Forfremmelse opbygges, mens langt meere hafver Aarsag at sucke ofver slige Forordninger.

4to. Alle udvortes Anstalter udj Kircke-Sager skall hafve Henseende til Meenigheds Opbyggelse og Forbedering, derimod og alt hvad som strieder imod Underviisning udj Lærdommen og Lefvnedts Forhold bör at strafves og afskaffes; hiertil kommer: 
5to. Deris Hoy Fürstl. Durchl. priissiærdige Niedkierhed til at handthæfve og holde ofver nyttelige Forordninger udj geistl. og værdsl. Sager, ng derfor vilde Deris Durchl. naadeligen behage, saasom det er ustridig

6to. at det ey staar udj Kirkens Patrons Vilkar og Villie inden forbend giefne Communication till det hoy (iffrighed som tillige medhaver Undersatterne udj samme Meenighed at forandre det som af Ardelss (!) Tiid formeedelst en god observance indfürte Kirke Forordninger, eller samme at ophæfre og afskafve, mens som

7 tio ved slige ny Anordninger Deris Hoy Fürstl. Durchl. höye Magt ofver Deris troe Undersatterne bliefver krencket og letteligen hereffter kunde giöre Anleedning til meere præjudicerlige Consequentier, saafremt som ey i Tiide ikke sligt hlifver forhindret og forekommen. Saa jndfalder til Deris Höy Fürstl. Durchl. vores underdanigste og ydmygeste Bön og Begiering, at De naadeligen vilde behage dette som ey alleene Deris Höy Fürstl. Durchl. Höyhed, mens endog vores og Paarörendes evige Velfærd angaar udj Christ. Fürstl. Betenkning at tage, og os Deris troe Undersatterne at antage, paa det hereffter som tilforn paa alle hellige og Syndage udj de Lycksbnrgske Kirker, udj hvilke Meenigheder vii ere Lemmer, bestændig udj det danske Sprag Guds Ord matte læres og forklares, saa og uden Deres Höy Fürstl. Durchl. naadigste Consens og Approbation ingen Forandring eller 
ny Anordninger udj Kirke-Sager matte blifve indfört

$$
\text { Herofver etc. }
$$

Till

Deris Höy Fürstl. Durchl. til Slesvig Holsteen

Synderborg

underdanigste Bön og Begiering

for

Deris Höy Fürstl. Durchl. Gravensteensche og Auenböllgaardske, udj de Lycksborgske Sonnewittske Kirkers tilligende Undersatter.

pro Clementissima

Resolutione ut jntus. 